\title{
FEATURE
}

\section{Right practice, right place: A conservation planning toolbox for meeting water quality goals in the Corn Belt}

Eileen L. McLellan, Keith E. Schilling, Calvin F. Wolter, Mark D. Tomer, Sarah A. Porter, Joe A. Magner, Douglas R. Smith, and Linda S. Prokopy

0 n August 2, 2014, the residents of Toledo, Ohio, were warned that their drinking water was potentially contaminated with microcystin, an algal-related toxin that can cause various illnesses and liver damage, and unsafe to drink (Bullerjahn et al. 2016). They were the latest victims of a series of water quality crises in the United States, many (including the Toledo event) attributable in large part to nutrients lost from agricultural landscapes. Meanwhile, hypoxia in the Gulf of Mexico continues unabated (USEPA 2015), with the 2017 dead zone being the largest recorded (NOAA 2017). In response to these crises, states in the Mississippi River and Great Lakes drainage basins are undertaking ambitious efforts to achieve $40 \%$ to $45 \%$ reductions in nutrient losses from agriculture.

There is a growing consensus that in-field conservation practices, such as improved nutrient management, conservation tillage, and cover crops, will not, singly or together, achieve the $45 \%$ nutrient reduction goals (Schilling and Wolter 2009; Iowa Nutrient Reduction Strategy 2013). Meeting these water quality goals will require combining in-field nutrient management practices with downstream nutrient removal practices, such as biore-

Eileen L. McLellan is a lead senior scientist with Environmental Defense Fund, based in Washington, DC. Keith E. Schilling is a research engineer with the College of Engineering at the University of lowa in lowa City, lowa. Calvin F. Wolter is a GIS analyst with the lowa Department of Natural Resources in Des Moines, lowa. Mark D. Tomer is a research soil scientist with USDA Agricultural Research Service (ARS) National Laboratory for Agriculture and the Environment in Ames, lowa. Sarah A. Porter is a physical science technician with USDA ARS National Laboratory for Agriculture and the Environment in Ames, lowa. Joe A. Magner is a research professor with the Department of Bioproducts and Biosystems Engineering at the University of Minnesota in St. Paul, Minnesota. Douglas R. Smith is a research soil scientist at USDA ARS Grassland Soil and Water Research Laboratory in Temple, Texas. Linda S. Prokopy is a professor of natural resources in the Department of Forestry and Natural Resources at Purdue University, in West Lafayette, Indiana. actors and filter strips at the edges of fields and wetland creation and floodplain restoration below fields (McLellan et al. 2015).

Edge-of-field and beyond-field practices are structural practices that require upfront investment but can deliver environmental benefits for 30 years or more if sited, designed, and managed correctly. To minimize disruption to existing row crop operations, these practices must be targeted to places on the landscape where they will be most effective (Lien and Magner 2017). In contrast to in-field conservation practices, like fertilizer optimization and cover crops, these "trap and treat" practices cannot necessarily be implemented on all fields and farms; they are only effective when they are situated to intercept significant nutrient flows (Crumpton et al. 2006). Implementing these practices effectively therefore requires a watershed-level understanding of nutrient flows to select the "right practice" to treat those flows and the "right place" along the flow path to intercept them-an analytical process that has not as yet been well incorporated into conservation planning.

To address this challenge, we developed the Right Practice, Right Place (RPRP) Toolbox, which has been designed to increase the efficiency and effectiveness of water quality improvement efforts. The RPRP Toolbox operationalizes a guiding scientific principle: to reduce nutrient loss, conservation efforts need to identify nutrient flow paths and opportunities to intercept and treat nutrients at strategic points along those flow paths. The Toolbox comprises a set of online conservation planning tools developed to link "right practice" to "right place" at regional, watershed, and field scales. The tools are available at the RPRP website at http://rprp.ags.io/ and associated links. In this paper, we describe the component tools and the process for using these tools in sequence to align conservation planning across multiple scales. However, we caution that using the tools effectively to guide water quality improvement efforts requires equal attention to the history and culture of the watershed and to prevailing attitudes and beliefs about water quality and the role of conservation. For example, Babin et al. (2016) describe the importance of understanding the social capacity of a watershed to undertake water quality improvement efforts, and Reimer et al. (2012) describe how perception of various conservation practices influences practice adoption. Thus, some level of socioeconomic understanding is key to successful use of the RPRP Toolbox and becomes increasingly important moving from regional to local scales.

\section{RIGHT PRACTICE, RIGHT PLACE: THE SCIENCE BEHIND THE TOOLBOX}

The Importance of Scale. The RPRP Toolbox is designed to help conservation planners at several different scales. Beginning at the regional scale, it is intended to help regional planners identify those small watersheds that are the major source of nitrogen $(\mathrm{N})$ exported downstream to the Gulf of Mexico, where investments of conservation funding are likely to make the biggest difference. Subsequently, the Toolbox helps planners identify, for a specific small watershed, those conservation practices best suited to the specific flow paths of that watershed. Finally, the Toolbox helps planners identify potential locations within the small watershed for implementing those practices. A key design consideration was that each of the different applications can be used independently yet be congruent with one another. For example, a regional planner may not be concerned with identifying specific fields for potential implementation of a specific practice, but the local conservation planner should be able to "see" the target watershed in both the regional context and in sufficient detail to map field-scale practice opportunities. For this reason, we built all the tools at a smaller watershed scale, specifically the hydrologic unit code (HUC)-12 scale (approximately 40 to $160 \mathrm{~km}^{2}$ [15 to $\left.62 \mathrm{mi}^{2}\right]$ ). This contrasts with the typical scale of watershed planning, usually done by state-level plan- 
ners at the larger HUC-8 scale. However, it is important to realize that the HUC-8 scale is not the scale of best management practice (BMP) implementation; frequently BMP planning and implementation occur at the scale of individual fields through the work of local USDA Natural Resources Conservation Service field and district offices and are not necessarily connected to plans developed for larger watersheds (e.g., Minnesota's Clean Water Legacy). Our selection of the HUC-12 scale is in part an effort to bridge the fieldlevel focus of traditional conservation efforts with the community and regional scales (HUC-8 and above) at which drinking water impairments and downstream eutrophication must be solved. Research suggests that the HUC-12 scale is typical of the scale of rural social networks (Babin et al. 2016). When landowners and operators know each other as neighbors, support for collective action to address water quality problems can become an issue of community pride (Magner 2011). An additional reason for preferring the HUC-12 scale is that headwater streams (which form a very large proportion of the stream network in larger watersheds) are extremely effective at removing $\mathrm{N}$ (Peterson et al. 2001); by working at the HUC-12 scale, it is possible to identify opportunities to enhance nutrient removal in the channels and riparian zones of these streams.

Identifying Priority Watersheds at Regional Scale. Federal and state agencies charged with improving water quality face limited and declining resources to address water quality challenges. This increases the importance of ensuring that scarce resources are directed to those locations where they will make the biggest difference. In the Mississippi River Basin, where the regional water quality concern is nitrate $\left(\mathrm{NO}_{3}^{-}\right)$export to the Gulf of Mexico, we have developed an online mapping tool that can be used to identify the HUC-12 scale watersheds that contribute the greatest loads of $\mathrm{N}$ to the Gulf. Our mapping tool is based on previous analysis using the US Geological Survey's Spatially Referenced Regressions on Watershed Attributes (SPARROW) Total Nitrogen Model for the upper Midwest (Robertson and Saad 2011) refined with more recent fertilizer data and downscaled to the HUC-12 scale (McLellan et al. 2015). Our analysis recognizes that downstream $\mathrm{N}$ export is determined both by levels of $\mathrm{N}$ input to the watershed and by the extent of instream processing to which that $\mathrm{N}$ is subject during transport. While the published analysis provides a regional overview of those watersheds that are hotspots for $\mathrm{N}$ export to the gulf, our mapping tool offers additional detail of the $\mathrm{N}$ load from individual watersheds, as shown in figure 1.

Identifying the "Right Practices" at the Small Watershed Scale. Once a specific HUC-12 watershed has been identified as a focus for conservation efforts, the next step is to determine the practices likely to be most effective in reducing nutrient loss in that watershed.Trap and treat nutrient removal practices, which can intercept and treat both particulate and dissolved nutrients along flow paths from cropland to receiving surface waters, are critical to achieving large reductions in nutrient export. However, for these practices to be effective they must intercept the actual flow of water and nutrients; for example, riparian buffers located above tile drains may successfully trap sediment and particulate phosphorus $(\mathrm{P})$ in surface runoff but provide little or no benefit for remov-

\section{Figure 1}

Screenshot of map of the Mississippi River Basin, showing portions of the states of Illinois, lowa, and Wisconsin. Blue lines correspond to the boundaries of hydrologic unit code (HUC)-12 watersheds. The fill color inside each HUC-12 corresponds to the ranking of the watershed in terms of nitrogen $(\mathrm{N})$ export to the Gulf of Mexico, with warmer colors corresponding to higher rankings. The user can zoom into individual HUC-12 watersheds to get more information.

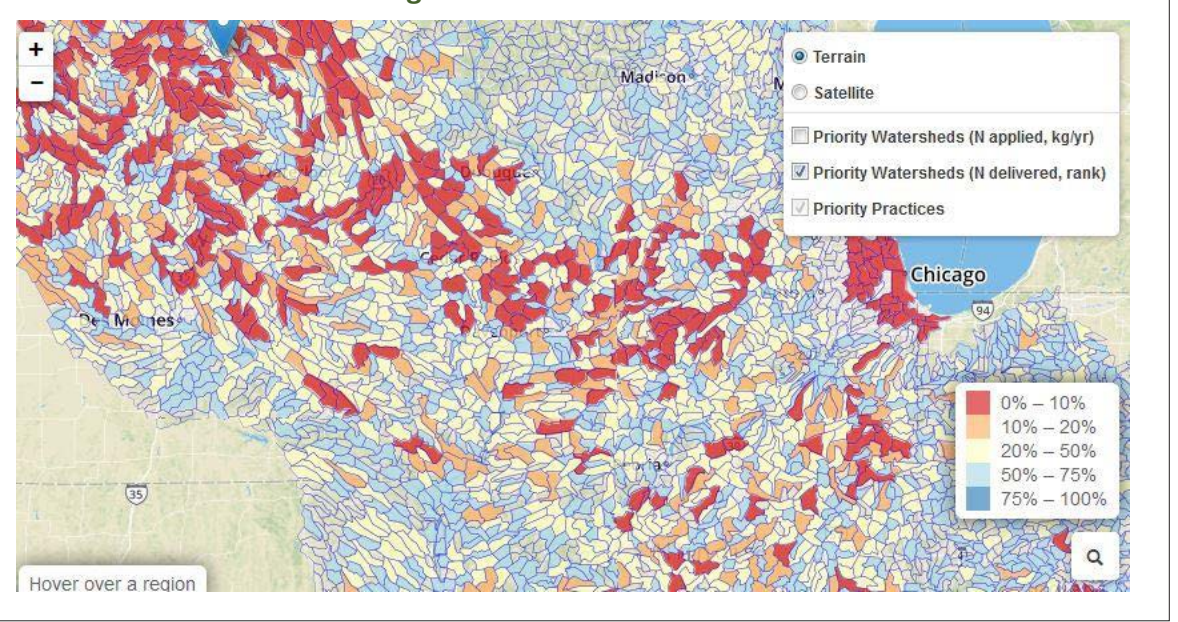




\section{Figure 2}

Agro-hydrologic landscapes of the Upper Mississippi River Basin (UMRB) and Ohio River Basin (ORB), modified after Schilling et al. (2015b). The dark blue line is the basin boundary. Each hydrologic unit code (HUC)-12 watershed in the basin in which agriculture is the dominant land use has been classified based on soil and topographic characteristics as described in the text. Different colors correspond to different agro-hydrologic classes, which represent different dominant flow paths and therefore the need for different sets of priority conservation practices. Classes A through $\mathrm{E}$ are described in the text.

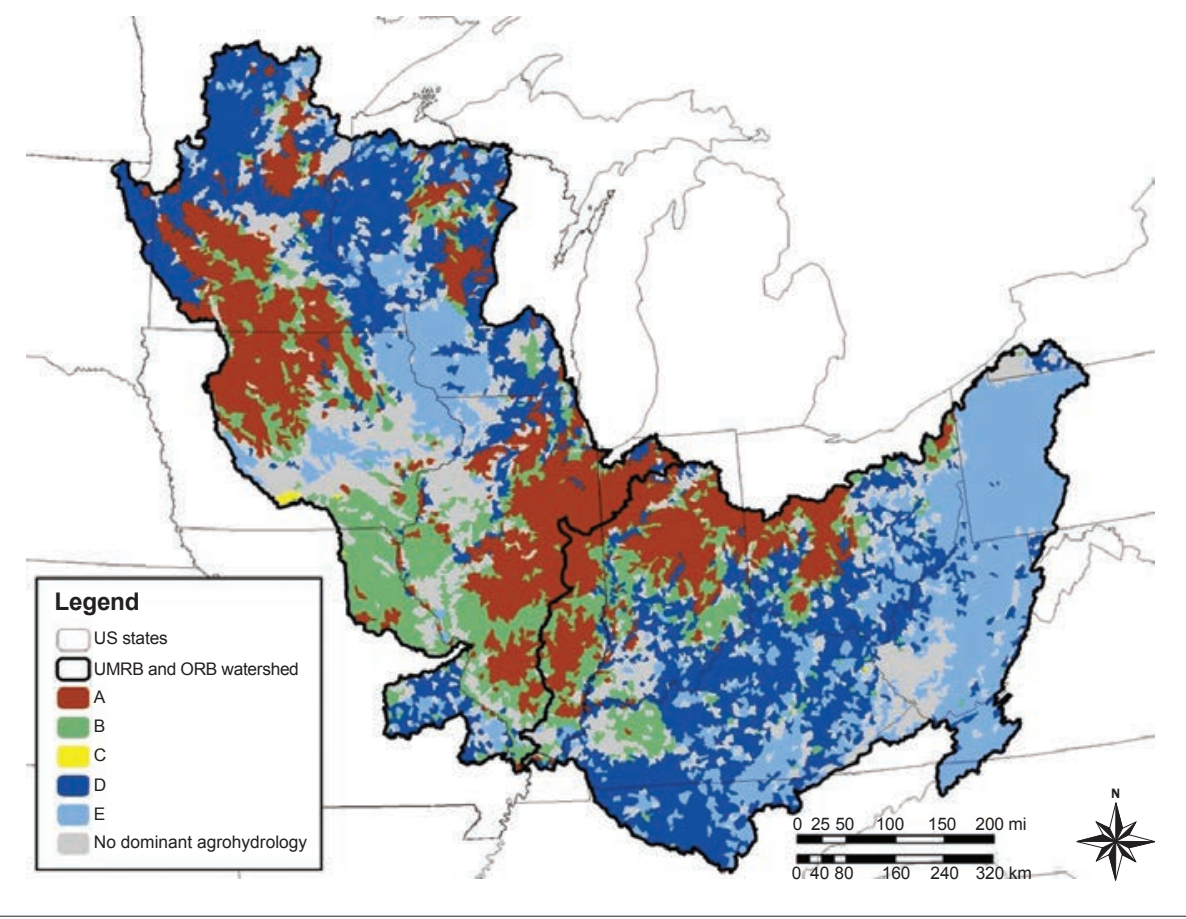

ent hydrologic flow paths. Watersheds in Class A, being poorly drained and with little topographic relief, are those most likely to be dominantly tile drained. Watersheds in Classes B and C, being poorly drained and with some degree of topographic relief, are likely to be dominated by surface runoff. Watersheds in Classes D and E, being well-drained, are likely to be dominated by subsurface flows regardless of the extent of topographic relief. Schilling et al. (2015b) further correlated these watershed classes, and their corresponding dominant flow paths, with the types of nutrient removal practices best-suited to reduce nutrient export.

We have expanded on this effort to identify, for each watershed class, the suite of conservation practices that should be matched to appropriate locations to decrease nutrient transport by trapping and/or transforming nutrients (table 1). Table 1 enables conservation planners to identify where BMP "stacking" or a "treatment train" (Magner 2011; Lien and Magner 2017) of practices can be implemented in series along flow paths from ridgetop to waterbody to maximize water quality improvement. We have integrated the information on agro-hydrologic land-

\section{Table 1}

Priority conservation practices by agro-hydrologic class, arranged by landscape position.

\begin{tabular}{|c|c|c|c|}
\hline \multirow[b]{4}{*}{ Landscape position } & \multicolumn{3}{|l|}{ Agro-hydrologic class } \\
\hline & $\mathbf{A}$ & B & D \\
\hline & \multicolumn{3}{|c|}{ Dominant flow path/primary focus of conservation efforts } \\
\hline & $\begin{array}{l}\text { Tile drainage/intercept } \\
\text { and treat tile drainage }\end{array}$ & Surface runoff/reduce erosion & $\begin{array}{l}\text { Subsurface runoff/reduce losses } \\
\text { from fields (limited opportunities } \\
\text { once nutrients are below root zone }\end{array}$ \\
\hline \multirow[t]{7}{*}{ In-field } & Nutrient management & Nutrient management & Nutrient management \\
\hline & Cover crops & Cover crops & Cover crops \\
\hline & Controlled drainage & Filter strips & \\
\hline & Blind inlets & Terraces & \\
\hline & Restore pothole wetlands & Conservation cover & \\
\hline & & Grass waterways & \\
\hline & & Conservation tillage & \\
\hline \multirow[t]{2}{*}{ Below field } & Bioreactors & Sediment detention basins & Spring/seep bioreactors \\
\hline & Nutrient removal wetlands & Farm ponds & \\
\hline Riparian zone & Re-saturated buffers & Riparian buffers & Riparian buffers \\
\hline \multirow[t]{3}{*}{ In-stream } & Two-stage ditches & Two-stage ditches & Floodplain reconnection \\
\hline & Floodplain reconnection & Floodplain reconnection & In-stream practices \\
\hline & In-stream practices & Instream practices & \\
\hline
\end{tabular}


scape class from figure 2 into the online mapping tool described above so that a conservation planner interested in a specific HUC-12 watershed can click on that watershed to see its agro-hydrologic class and the corresponding hypothesized suite of "priority" conservation practices, as shown in figure 3.

Identifying the "Right Places" at the Small Watershed Scale. Once a conservation planner or other interested party has identified from table 1 the suite of "priority" conservation practices best suited for a specific watershed, the next step is to evaluate where these practices could potentially be located within the watershed. The Agricultural Conservation Planning Framework (ACPF) comprising a land use and soils database (Tomer et al. 2017) and ArcGIS toolbox (Porter et al. 2016) has been made available to help planners identify potential practice locations for a variety of practices at the small watershed scale (Tomer et al. 2013b; 2015). The ACPF applies flexible criteria to spatial data on terrain, soils, and land use to identify practice locations. Figure 4, for example, shows locations in the Beargrass Creek watershed in northeast Indiana where it is feasible to construct nutrient removal wetlands to intercept tile drainage based on specific criteria related to flow accumulation, wetland:watershed ratio, and soil drainage. The potential practice locations can then be ranked in terms of the amount of nutrient reduction they can potentially achieve based on information about land use and tile drainage of the subwatershed contributing areas, as described in Tomer et al. (2013a). This helps show where conservation funds can be spent most effectively.

Developing Conservation Scenarios: Putting "Right Practices"' and "Right Places" Together to Achieve Water Quality Goals. Mapping the potential "right places" for all the potential "right practices" in a watershed allows local stakeholders to work with scientists to identify those practice implementation opportunities of greatest interest. Figure 5 shows such a map for the Beargrass Creek watershed in northeast Indiana. Potential practices include drainage water management (in-field, N), blind inlets installed in shallow depressions (in-field, P), bioreactors (edge-of-field, N), nutrient removal wetlands

\section{Figure 3}

Screenshot of map showing Rock Run, a hydrologic unit code (HUC)-12 watershed in the same region as figure 1, which exports high loads of nitrogen $(N)$ to the Gulf of Mexico as shown by the red fill color. The agro-hydrologic classification of the watershed ("well-drained, high slopes") is also shown, and below is the suite of recommended conservation practices for this watershed based on that classification.

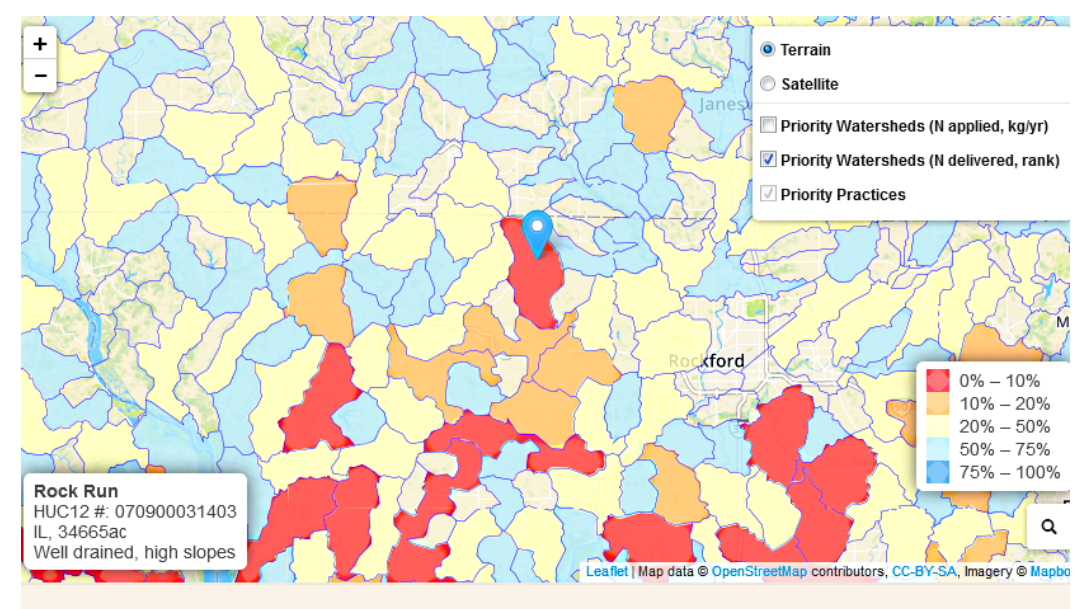

Recommended Conservation Practices

\section{Rock Run}

HUC12 \#: 070900031403

IL, 34665ac

Well drained, high slopes

\begin{tabular}{|c|c|c|c|}
\hline In Field & Below Field & Riparian Zone & Downstream \\
\hline Cover Crops & & Riparian Buffers & Floodplain Reconnection \\
\hline Nutrient Management & & & In-stream Practices \\
\hline
\end{tabular}

Nutrient Management

In-stream Practices

Extended Rotation

Conservation Tillage

installed below large tile outlets (below-field, $\mathrm{N})$ and two-stage ditches, as well as numerous practices for runoff control. In addition, figure 5 shows several near-stream depressions, which may offer opportunities for creating off-stream wetlands by diverting stream water into carbon (C)-rich soils. As stakeholders identify and rank their interest in various practices and practice locations, it is possible to create a set of conservation scenarios that, if implemented, would achieve the target level of nutrient reduction at the watershed outlet. Tomer et al. (2015) provide a spreadsheet-based approach for evaluating whether a proposed scenario will achieve the target reduction.

\section{USING THE RIGHT PRACTICE, RIGHT PLACE TOOLBOX AT THE SMALL WATERSHED SCALE}

The RPRP Toolbox is designed to be used by natural resources planners and watershed organization staff as a way of facilitating dialog with local stakeholders about water quality challenges and opportunities for improvement. It provides a science-based framework for identifying potential conservation scenarios that, if implemented, would achieve desired water quality goals. We used the RPRP Toolbox in several small watersheds across the Corn Belt as a way of engaging local stakeholders in community-based watershed planning designed to achieve $45 \%$ reductions in nutrient loss. Anecdotally, we found that stakeholders appreciated the opportunity to learn more about the science behind nutrient loss; that local ingenuity led to the design of several very innovative nutrient removal practices, which we attempted to incorporate into the planning process; and that local knowledge of the watershed was critical to identifying both physically viable and socially acceptable practice 


\section{Figure 4}

Potential locations for nutrient removal wetlands in Beargrass Creek, northeast Indiana, identified using the Agricultural Conservation Planning Framework. The base map is a processed LiDAR image of the watershed, and blue lines represent the stream network. Nutrient removal wetlands are constructed to intercept tile drainage; siting criteria include appropriate drainage area (to ensure that they intercept a large flow), an appropriate wetland to watershed ratio (to facilitate nutrient removal), and embankment height. They are constructed with a grassed buffer area to prevent sediment transport into the wetland, which would reduce its life expectancy.
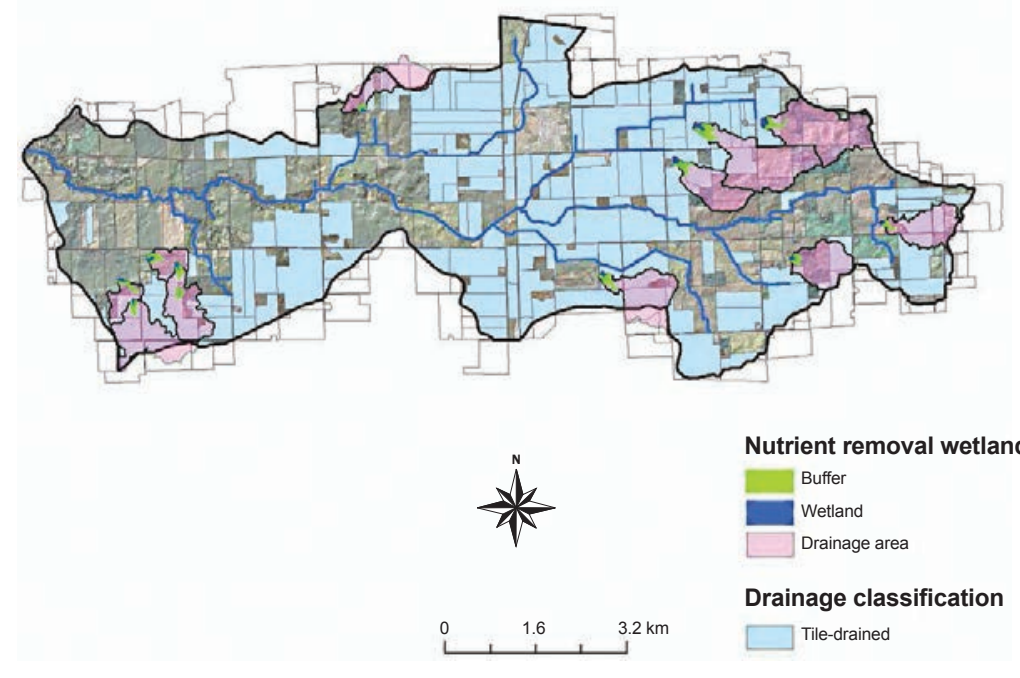

\section{Figure 5}

Potential conservation practice opportunities to reduce nitrogen $(\mathrm{N})$ and phosphorus $(P)$ loss for Beargrass Creek, Indiana. Potential practices include drainage water management (in-field, N), blind inlets installed in shallow depressions (in-field, P), bioreactors (edge-of-field, $\mathrm{N}$ ), nutrient removal wetlands installed below large tile outlets (below-field, N), and two-stage ditches, as well as numerous practices for runoff control. In addition, shown in light blue, are several near-stream depressions, which may offer opportunities for creating off-stream wetlands.

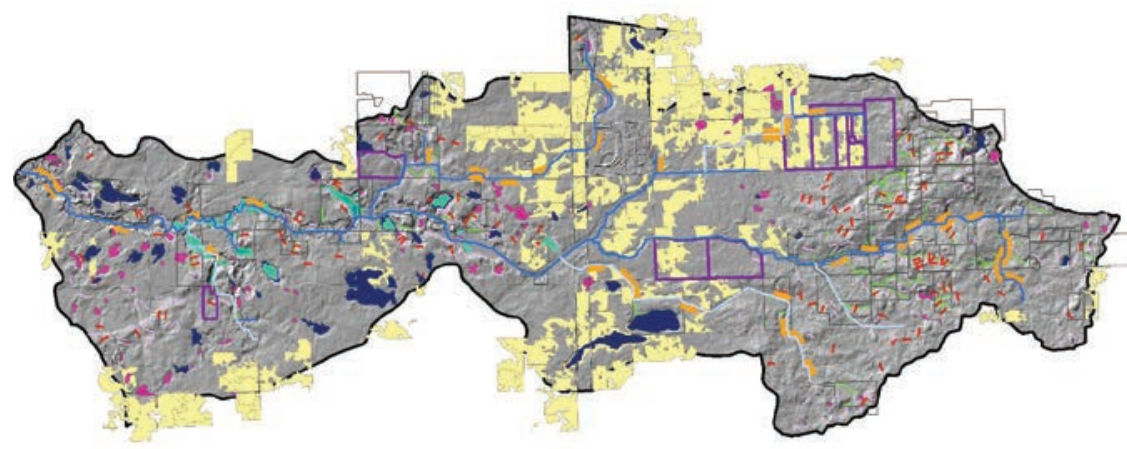

In-field practices

Drainage management opportunities In-field surface depressions

Depressions with likely tile intakes (classified by depth) $<1 \mathrm{~m}$

Runoff control

$\square$ Steeper fields ( $>25 \%$ of field is $>4 \%$ slope)

WASCOBS (water and sediment control basins)

Grass waterways ( $>2$ ha drainage)

Contour buffer strips

\section{Riparian practices}

Two-stage ditch possibilities

Depressions along stream (divert and treat) Estimated water table depth

$\square$ Channel

0 to $50 \mathrm{~cm}$

50 to $100 \mathrm{~cm}$

100 to $150 \mathrm{~cm}$

Riparian function

Critical zone/multispecies buffer locations. Our efforts to integrate the biophysical science incorporated in the RPRP Toolbox with the social and economic setting of the watershed led us to develop the watershed approach, which will be described elsewhere.

\section{COMPARISON WITH OTHER CONSERVATION PLANNING TOOLS}

The RPRP Toolbox is designed to provide a science-based framework to improve regional water quality improvement efforts by making them more efficient and effective. Our emphasis in designing the Toolbox was to ground it in hydrology by emphasizing the importance of nutrient flows at the regional, small watershed, and even subwatershed scale. Equally important to our vision was making the RPRP Toolbox scalable across a region the size of the Mississippi River Basin; this led us to use the agro-hydrologic landscape concept for identifying priority practices and prompted us to develop public, online access to the component tools. Although the RPRP Toolbox and its component planning tools have been developed specifically for the Mississippi River Basin, the basic design principles are easily transferable to other regions such as the Great Lakes and Chesapeake Bay.

The Toolbox is in no way intended to replace local planning efforts, which leverage detailed information on watershed conditions and use more sophisticated modeling tools to simulate nutrient sources, flow paths, and sinks (Jha et al. 2010). These efforts typically extend over long time frames and are supported by significant investments of resources in data collection and model development, as well as significant investments in staff capacity by local, state, and federal agencies. Our assumption, in developing this Toolbox, has been that this level of investment will not be available for the many hundreds or thousands of small watersheds in which water quality improvements will be needed if regional water quality goals are to be met.

We likewise believe that the RPRP Toolbox could be a useful supplement to tools that have already been developed by several midwestern states to support their nutrient reduction strategies. For 
example, Minnesota's Watershed Nitrogen Reduction Planning Tool (Lazarus et al. 2014) provides a spreadsheet that allows a user to identify a set of BMPs and implementation levels that are optimized for cost and effectiveness at watershed scale. While it recognizes that different BMPs are best suited for different hydrologic settings, it does not attempt to help the user identify the relevant hydrologic setting and corresponding priority conservation practices for a specific watershed. We suggest that using the RPRP Toolbox first, to identify priority practices, would provide biophysical guidance for subsequent use of the Nitrogen Reduction Planning Tool, and that once the user has identified the optimal mix of practices and practice implementation levels from that tool they could return to our Toolbox to identify viable practice locations.

\section{ACKNOWLEDGEMENTS}

We acknowledge support from the Walton Family Foundation and USDA Natural Resources Conservation Service Conservation Innovation Grants \#69-3A75-11-223 and \#69-3A75-13-239 for the development of the RPRP Toolbox and its application in various watersheds.

\section{REFERENCES}

Babin, N., N.D. Mullendore, and L.S. Prokopy. 2016. Using social criteria to select watersheds for nonpoint source agricultural pollution abatement projects. Land Use Policy 55:327-333.

Bullerjahn, G.S., R.M. McKay, T.W. Davis, D.B. Baker, G.L. Boyer, L.V. D’Anglada, G.J. Doucette, J.C. Ho, E.G. Irwin, C.L. Kling, and R.M. Kudela. 2016. Global solutions to regional problems: Collecting global expertise to address the problem of harmful cyanobacterial blooms. A Lake Erie case study. Harmful Algae 54:223-238.

Crumpton, W.G., G.A. Stenback, B.A. Miller, and M. Helmers. 2006. Potential benefits of wetland filters for tile drainage systems: Impact on nitrate loads to Mississippi River sub basins. Final report to USDA. Project number: IOW06682. Ames, IA: Iowa State University. https://www.fsa.usda.gov/Internet/ FSA_File/fsa_final_report_crumpton_rhd.pdf.

Iowa Nutrient Reduction Strategy. 2013. Iowa Nutrient Reduction Strategy. Ames, IA: Iowa State University Science Team. http://www. nutrientstrategy.iastate.edu/sites/default/files/ documents/INRS-2-161001.pdf.
Jha, M.K., C.F. Wolter, K.E. Schilling, and P.W. Gassman. 2010. Assessment of total maximum daily load implementation strategies for nitrate impairment of the Raccoon River, Iowa. Journal of Environmental Quality 39(4):1317-1327.

Lazarus, W.F., D.J. Mulla, and D. Wall. 2014. A spreadsheet planning tool for assisting a state agency with cost-effective watershed scale surface water nitrogen planning. Journal of Soil and Water Conservation 69(2):45A-50A, doi:10.2489/ jswc.69.2.45A.

Lien, E., and J. Magner. 2017. Engineered biosystem treatment trains: A review of agricultural nutrient sequestration. Invention Journal of Research Technology in Engineering and Management 1(11):1-8.

Magner, J. 2011. Tailored watershed assessment and integrated management (TWAIM): A systems thinking approach. Water 3(2):590-603.

McLellan, E., D. Robertson, K. Schilling, M. Tomer, J. Kostel, D. Smith, and K. King. 2015. Reducing nitrogen export from the Corn Belt to the Gulf of Mexico: Agricultural strategies for remediating hypoxia. Journal of the American Water Resources Association 51(1):263-289.

NOAA (National Oceanic and Atmospheric Administration). 2017. Gulf of Mexico 'dead zone' is the largest ever measured. http://www. noaa.gov/media-release/gulf-of-mexico-deadzone-is-largest-ever-measured.

Peterson, B.J., W.M. Wollheim, P.J. Mulholland, J.R. Webster, J.L. Meyer, J.L. Tank, E. Martí, W.B. Bowden, H.M. Valett, A.E. Hershey, and W.H. McDowell. 2001. Control of nitrogen export from watersheds by headwater streams. Science 292(5514):86-90.

Porter, S.A., M.D. Tomer, D.E. James, and K.M. Boomer. 2016. Agricultural Conservation Planning Toolbox User's Manual. Madison, WI: North Central Region Water Network. www. northcentralwater.org/acpf/.

Reimer, A.P., D.K. Weinkauf, and L.S. Prokopy. 2012. The influence of perceptions of practice characteristics: An examination of agricultural best management practice adoption in two Indiana watersheds. Journal of Rural Studies 28(1):118-128.

Robertson, D.M., and D.A. Saad. 2011. Nutrient inputs to the Laurentian Great Lakes by source and watershed estimated using SPARROW watershed models. Journal of the American Water Resources Association 47(5):1011-1033.

Schilling, K.E., and C.F. Wolter. 2009. Modeling of nitrate-nitrogen load reduction strategies for the
Des Moines River using SWAT. Environmental Management 44(4):671-682.

Schilling, K.E., C.F. Wolter, T.M. Isenhart, and R.C. Schultz. 2015a. Tile drainage density reduces groundwater travel times and compromises riparian buffer effectiveness. Journal of Environmental Quality 44(6):1754-1763.

Schilling, K.E., C.F. Wolter, and E. McLellan. 2015b. Agro-hydrologic landscapes in the upper Mississippi and Ohio River basins. Environmental Management 55(3):646-656.

Tesoriero, A.J., J.H. Duff, D.M. Wolock, N.E. Spahr, and J.E. Almendinger. 2009. Identifying pathways and processes affecting nitrate and orthophosphate inputs to streams in agricultural watersheds. Journal of Environmental Quality 38(5):1892-1900.

Tomer, M.D., W.G. Crumpton, R.L. Bingner, J.A. Kostel, and D.E. James. 2013a. Estimating nitrate load reductions from placing constructed wetlands in a HUC-12 watershed using LiDAR data. Ecological Engineering 56:69-78.

Tomer, M.D., D.E. James, and C.M. Sandoval-Green. 2017. Agricultural Conservation Planning Framework: 3. Land use and field boundary database development and structure. Journal of Environmental Quality 46(3):676-686.

Tomer, M.D., S.A. Porter, K.M. Boomer, D.E. James, J.A. Kostel, M.J. Helmers, T.M. Isenhart, and E. McLellan. 2015. Agricultural conservation planning framework: 1. Developing multi-practice watershed planning scenarios and assessing nutrient reduction potential. Journal of Environmental Quality 44(3):754-767.

Tomer, M.D., S.A. Porter, D.E. James, K.M. Boomer, J.A. Kostel, and E. McLellan. 2013b. Combining precision conservation technologies into a flexible framework to facilitate agricultural watershed planning. Journal of Soil and Water Conservation 68(5):113A-120A, doi:10.2489/jswc.68.5.113A.

USEPA (US Environmental Protection Agency). 2015. Mississippi River/Gulf of Mexico Watershed Nutrient Task Force: 2015 Report to Congress. Washington, DC: Mississippi River/ Gulf of Mexico Watershed Nutrient Task Force.

Wolock, D.M., T.C. Winter, and G. McMahon. 2004. Delineation and evaluation of hydrologic-landscape regions in the United States using geographic information system tools and multivariate statistical analyses. Environmental Management 34(1):S71-S88. 